\title{
Miguel Ciera: um demarcador de limites no interior sul-americano (1750-1760)
}

\begin{abstract}
Maria de Fátima Costa ${ }^{1}$
RESUMO: Estudam-se os trabalhos produzidos por Miguel Ciera tendo como pano de fundo a viagem realizada pela Terceira Partida de Limites, que, por ordem de Portugal, percorreu o interior da América Meridional entre 1752-1756. Na função de astrônomo e cosmógrafo da equipe demarcadora, este engenheiro paduano subiu o rio Paraguai até alcançar a boca do Jauru e ali, junto com seus companheiros, fixou o marco divisório, substanciando in loco o Tratado de Limites. Foi durante esta viagem que Ciera colheu informações para construir o seu Mappa geographicum quo flumen Argentum, Paranà et Paraguay [...], um belo atlas, com o qual presenteou o rei Dom José I em 1758. Nele, além de precisas cartas geográficas, registrou a lápis e a aquarela elementos da fauna, tipos populares e vistas de paisagens, criando o primeiro conjunto iconográfico da região que, no século XVIII, passou a receber o nome de Pantanal. Neste artigo, analisa-se esta obra, buscando demonstrar que ela não se constituiu apenas num belo atlas, mas que se trata de um refinado documento visual com o qual Miguel Ciera oferece ao monarca de Portugal as mais primorosas informações sobre os territórios interiores nos quais se traçou a linha de limites.

PALAVRAS-CHAVE: Expedição de Limites. Miguel Ciera. Iconografia sul-americana. Pantanal.

ABSTRACT: In this paper, we examine the works produced by Miguel Ciera against the backdrop of the Third Delimitation Expedition, which was sent by Portugal to explore the interior of South America between 1752 and 1756. As the astronomer and cosmographer of the demarcation team, this Paduan engineer sailed up Paraguay River all the way to the mouth of Jauru River and there, with his companions, he set the border line, thus substantiating at site the Treaty of Boundaries. It was during this expedition that Ciera gathered information to design his Mappa geographicum quo flumen Argentum, Paranà et Paraguay [...], a beautiful atlas that he later bestowed upon King Joseph I in 1758. In addition to accurate geographic charts, the atlas included depictions of fauna, popular types and landscapes made in pencil and watercolor, forming the first set of images available of that region, which was named Pantanal as from the $18^{\text {th }}$ century. Here, we analyze this specific piece and seek to demonstrate that it was not merely a beautiful atlas; in fact, it was a refined visual document with which
\end{abstract}

1. Docente da Universidade

Federal do Mato Grosso.

E-mail: <mfcosta@ufmt.br> 
2. Tu rex, Tu magnus: causa rogata mea est. / Forsitan et nostris jam delectaberis ausis: / iure tuum est quidquid pagina picta docet. / Fecimus et iussi, tua nos ad regna vocasti, / ausoniosque lares liquimus, et patriam / Pacta fides ultro longínqua ad littora cursu / tendere, qua serus Sol pater urget equos ./ Fluminaque, et prata, et silvas, montesque lacusque / metiri, et certo figere quaque loco / Praecipue terras magni confinia regni / hispano per quas dividis império. Miguel Ciera (1758). Cart. 90559. Fundação Biblioteca Nacional, Rio de Janeiro. Obra oriunda da Real Biblioteca.

3. Mappa geograpbicum quo flumen Argentum, Paranà et Paraguay exactissime nunc primum describuntur, facto inito a nova Colonia ad ostium usque fluminis iauru ubi, ex pac tis finuim regundorum, Terminus de mármore positus, terrarumque insigniores Prospectus, et quorun dam animalium forme suis quaelibet aptae delineantur. Opera, ac Studio Michaelis Ciera R. F. geographi. Fundação Biblioteca Nacional, Rio de Janeiro. Obra oriunda da Real Biblioteca.

4. Sabemos que não se utilizavam, no século XVIII, as palavras cartografia e cartó grafo, muito menos o verbo cartografar, já que, tal como informa L. Martín Merás (1993, p. 13): "la palabra cartografía es un neologismo puesto en circulación por el estudioso portugués Manuel Francisco de Barros e Souza, vizconde de Santarém, en la segunda mitad del siglo XIX para referirse al estudio de los mapas antiguos. El significado de la palabra ha se ampliado desde entonces, pues incluye también el arte y la ciencia de construir mapas contemporáneos". Empregamos aqui esses termos para facilitar a narrativa e a compreensão do texto.
Miguel Ciera offered the Portuguese monarch valuable information about the hinterland where the border line was laid.

KEYWORDS: Delimitation Expedition. Miguel Ciera. South American iconography. Pantanal.

Tu, ó rei, Tu és grande: és a causa dos meus pedidos. Talvez, desde já, serás também seduzido pelos nossos clamores: com razão é teu tudo aquilo que a página traçada ensina. Fizemos como mandaste, nos chamaste para o teu reino, e abandonamos os lares ausônios, e avançamos a pátria conforme acordo para além da região do litoral, para onde o pai Sol impele os cavalos. Percorrer os rios, os prados, as florestas, os montes e o lago, e fixar em determinado e qualquer lugar sobretudo as terras limítrofes do grande reino em que divides o império espanhol. ${ }^{2}$

Estes versos, escritos por Miguel Ciera em 1758, estão entre os 47 dísticos latinos com os quais dedicou um preciso atlas manuscrito ao rei $D$. José I, de Portugal, obra que hoje pertence ao acervo cartográfico da Biblioteca Nacional no Rio de Janeiro ${ }^{3}$. Nele, tal como expressa o título, descrevem-se os rios da Prata, Paraná e Paraguai, desde a Colônia de Sacramento até o rio Jauru, no interior sul-americano. Trata-se de um conjunto de representações, em aquarela, que mostra paisagens e cidades, tipos populares, elementos da fauna e, principalmente, mapas. São testemunhos pictóricos dos lugares por onde Miguel Ciera andou durante os anos de 1752 e 1756, quando esteve empregado como astrônomo da Terceira Partida de Limites portuguesa; o conjunto constitui, hoje, o primeiro registro visual sobre a paisagem interior da América Meridional. Miguel Ciera, com graça e acerto, levou ao papel lugares como a serra de São Fernando, os morros Pão de Açúcar e Três Irmãos e a lagoa Gaíba - motivos inaugurais da iconografia destas belas terras interiores, da região que, no final do século XVIII, ganhou o nome de Pantanal, cuja paisagem hoje é considerada Patrimônio da Humanidade.

Miguel Antonio Ciera, natural de Pádua, chegou a Lisboa em 1751. Era um dos estrangeiros empregados pela Corte lusa para viajar à América Meridional, e ali reconhecer e cartografar ${ }^{4}$ o território que acabava de ser fixado como fronteira entre as colônias ibéricas, de acordo com o tratado que os reis de Portugal e Espanha assinaram em Madri, em janeiro de 1750.

Pouco se sabe sobre a vida deste astrônomo antes de estabelecer relações com os portugueses. Certamente foi contratado ainda em 1750, e é fato que, já em junho do ano seguinte, estava em Lisboa, onde, juntamente com outros colegas estrangeiros, teve oportunidade de observar um eclipse lunar ${ }^{5}$.

Quanto à vida pessoal, não se conhece a data de seu nascimento, mas é provável que nosso personagem estivesse com uma idade próxima aos 25 anos quando chegou a Portugal. Cogita-se que, ao viajar à América, Ciera ainda era solteiro, mas, após o seu retorno, teria contraído núpcias em Lisboab. Sabemos que foi casado com Dona Antonia Margarida Violante de Lima, com quem teve quatro filhos ${ }^{7}$; um deles, Francisco António de Ciera, seguirá os passos do pai, vindo a tornar-se um eminente cartógrafo. 
Como demarcador, Ciera fez parte da denominada Terceira Partida do Sul, tropa de limites que, a mando de Portugal, reconheceu os rios da bacia platina entre o Paraguai e o Jauru, assim como as águas do Paraná até o seu grande salto. Além disso, depois de concluir as tarefas demarcatórias - juntamente com José Custódio de Sá e Faria, Gregório de Castro e João Bento Pinton, todos empregados na mesma Partida -, ofereceu seus serviços a Gomes Freire de Andrade, comissário principal da demarcação portuguesa, e o acompanhou quando este general comandou as tropas lusas que se dirigiam às missões jesuíticas, em campanha contra os índios, na guerra Guaranítica ${ }^{8}$. E o nosso demarcador efetivamente esteve no front, tornando-se, nas palavras de Ângelo Blasson, um testemunha ocular do "massacre que se fez no dia 10 de fevereiro, de um corpo de 2.000 índios" 9 . Presenciou, pois, a sangrenta batalha de Caiboaté, quando as tropas luso-castelhanas enfrentaram o exército de índios que defendia o território missioneiro, combate em que foi morto o líder Sepé Tiarajú. Em 1756, já o encontramos de volta a Lisboa, onde, ainda conforme o mesmo Blasson, levou à corte, como Carta Viva, o relato daquele massacre.

Em Portugal, Ciera solicita permissão para voltar à ltália, mas tem o pedido negado. $O$ rei ainda precisava dos seus serviços. Tudo indica que os trabalhos realizados como demarcador abriram-lhe portas no universo luso. Mas não apenas isso: enquanto esteve na América, o engenheiro paduano conquistou a admiração de Freire de Andrade que, em cartas a Sebastião José de Carvalho, então secretário dos Negócios Estrangeiros e Guerra, teceu-lhe fartos elogios, a exemplo do que se segue:

O Dr. Miguel Ciera não só deu em esta ocasião prova de grande ciência na sua profissão, mas a de que obra com zelo de bom Português; [... a além de Astronomia é na Geografia, e acertado e mimoso risco tão particular, que o não excede algum dos Oficiais, que servem neste Exército: é certo, ele havia findo o trabalho a que foi destinado, e eu the segurei podia recolher-se ao Rio de Janeiro para voltar a essa Corte; mas ele o não admitiu segurando-me havia de fazer primeiro esta Campanha [guerra Guaranítica] donde entende pode o seu trabalho ser útil: vai em minha companhia e eu seguro a Vossa Excelência este homem é muito capaz de servir em esta Corte quando a ela retornar ${ }^{10}$.

Recomendações como esta, certamente, serviram-lhe como salvo-conduto. Pouco tempo depois de retornar à Europa, Miguel Ciera já exercia funções institucionais na Corte. Porém, nos dois primeiros anos em Lisboa, ainda realizou trabalhos ligados à demarcação, finalizando ou copiando as cartas geográficas sul-americanas. Sabemos disto através de Requerimento que fez a $D$. José, em 1758, solicitando o pagamento do soldo correspondente a esse tempo de serviço. E foi nesse mesmo ano de 1758 que Ciera preparou o Mappa geographicum quo flumen Argentum, Paranà et Paraguay [...], o atlas manuscrito inicialmente referido. Nele, além de louvar ao rei, evoca as qualidades do seu protetor Gomes Freire de Andrade, a quem denomina de "o grande Freire" 11.

Certamente os bons serviços realizados, somados à cumplicidade com
5. Cf. R. Carvalho (1985, p. 67-68). A presença dos estrangeiros em Lisboa estava ligada aos trabalhos de demarcação; tal como Ciera, em 1750 foram contratados no exterior mais de uma dezena de profissionais versados em matemática e astronomia, para realizar a demarcação na América. Na época, Portugal não contava em seus quadros com profissionais habilitados para este serviço. Ver carta de Pedro Mota e Silva, em J. Cortesão, (1952, p. 42).

6. Ver M. C. Ferreira (2001, p. 255).

7. AHU, cx. 188, doc. 13577.

8. AHU, Brasil - Limites, cx. 1, doc. 93; 25 dez. 1755

9. AHU, Brasil - Rio de Janeiro, cx. 85 , doc. $19.643 ; 5$ maio [mar.] 1756.

10. AHU, Brasil - Limites, cx. 1, doc. 93. Grifo da autora. Nesta e em todas as citações extraídas de manuscritos e fontes impressas referidas neste artigo, a ortografia foi atualizada e as abreviaturas desdobradas.

11. Haec ego mirabar, Freire dum magnus ad urbem [...] Hic Vir, bic est cui tot rerum moderamina credis, / et quo non alter carior urbe fuit. Miguel Ciera (1758). 
12. AHU, Brasil - Rio de Janeiro, cx. 188, doc. 13577 . Informações sobre Ciera podem ser encontradas em $\mathrm{R}$. Carvalho (1959; 1985); e em M. C. Ferreira (2001).

13. A referência às partidas, além do fato de serem três, está no plural devido a que, mesmo que viajassem juntos, portugueses e espanhóis formaram, de fato, duas equipes distintas, cada uma com seus respectivos chefes, sendo nominadas, em separado, de Terceira Partida portuguesa e Terceira Partida espanhola.
Freire de Andrade, foram um abre-alas para Ciera, facilitando-the a vida na Corte. E, iá em 1760, esteve envolvido no projeto de criação do Real Colégio dos Nobres, instituição na qual será Prefeito dos Estudos. Ficou nesse posto até 1772, quando foi mandado a ensinar astronomia na reformada Universidade de Coimbra. Ali se tornou professor de figuras como Antonio Pires da Silva Pontes e Francisco José de Lacerda e Almeida, futuros demarcadores de limites no pós-tratado de Santo Ildefonso. Porém, em 1780, voltou a Lisboa, para estabelecer a Real Academia da Marinha. Lá ensinou trigonometria-esférica e arte da navegação teórica e prática, até o dia do seu falecimento, em setembro de $1782^{12}$. Somavam-se trinta e dois anos de serviço prestado ao governo lusitano.

Neste artigo, entretanto, o foco recai sobre o tempo em que Ciera esteve na América Meridional, mais exatamente os anos de 1753-1754, quando - na função de astrônomo-cosmógrafo - integrou a Terceira Partida portuguesa, que subiu o rio Paraguai até alcançar a boca do Jauru e ali "plantou" o marco divisório, substanciando in loco o Tratado de Limites. Foi durante esta viagem que colheu informações para construir o seu Mappa geographicum quo flumen Argentum, Paranà et Paraguay [...], objeto deste estudo. Pretende-se, pois, analisar esta obra no contexło da Demarcação de Limites, de forma a demonstrar que não apenas constituiu um belo livro, mas, sim, um meio pelo qual Miguel Ciera ofereceu ao monarca de Portugal as mais primorosas informações sobre os territórios interiores, onde se traçava a linha de fronteira. Inicialmente será feito um breve relato do processo demarcatório, da viagem e dos trabalhos realizados pela Terceira Partida, para depois adentrar na obra de Ciera.

\section{A demarcação}

Ainda no século XVIII, as questões de limites entre as colônias ibéricas eram norteadas pelo que foi estabelecido em Tordesilhas, no ano de 1494. Por este acordo, Portugal recebia uma faixa litorânea na costa atlântica sul-americana, enquanto os territórios a oeste ficavam sob a tutela da Espanha. Porém, ao iniciar os Setecentos, os súditos lusitanos já haviam avançando além desses limites. No norte, adentraram na Amazônia; no sul, ocuparam a margem oriental do rio da Prata e ali fundaram, em 1680, a Colônia do Sacramento e, no sentido oeste ao encontrarem ouro - criaram núcleos de povoação em Cuiabá e em Mato Grosso. Contudo, oficialmente, tais territórios ainda eram espanhóis. Colocava-se, pois, um problema de fronteiras e de definição de limites.

Empenhados em resolver a questão, os reinos ibéricos negociaram e assinaram, em 1750, o Tratado de Madri. Comissões mistas - formadas por espanhóis e lusitanos - foram enviadas à América: uma para o norte e outra no sentido oposto, subdivididas em três tropas ou partidas ${ }^{13}$. Cada uma destas tropas esteve composta por cosmógrafos, responsáveis pelos trabalhos de astronomia e cartografia; alferes, para o mando dos soldados; capelães, para os remédios 
espirituais; e cirurgiões, para as enfermidades do corpo. A eles se somavam soldados índios, escravos-negros para o serviço, pilotos e demais trabalhadores.

Interessa-nos, aqui, a Terceira Partida portuguesa que percorreu o sul'14, pois aí estava empregado o paduano Miguel Antonio Ciera, na equipe que recebeu como tarefa realizar o que estipulava o artigo VI do Tratado:

Desde a boca do Igureí continuará pelo álveo acima até encontrar a sua origem principal: e dali buscará em linha reta pelo mais alto do terreno a cabeceira principal do rio mais visinho que deságua no Paraguai pela sua margem oriental, talvez será o que chamam Corrientes, e baixará pelo álveo deste rio até a sua entrada no Paraguai, desde a qual boca subirá pelo canal principal que deixa o Paraguai em tempo seco; e pelo seu álveo até encontrar os pântanos que forma este rio, chamados a Lagoa dos Xarais, e atravessando esta Lagoa, até a boca do rio Jauru. ${ }^{15}$

Para realizar tais trabalhos, além desses profissionais capazes, as tropas contaram com um valioso arsenal científico. Para que os seus representantes pudessem efetivar o que lhes havia sido determinado, tanto Espanha como Portugal haviam adquirido os mais modernos instrumentos de medição, nos principais centros europeus, notadamente na Inglaterra.

Instrumentos e livros na demarcação

Graças a uma Lista, guardada no Arquivo Histórico Ultramarino (AHU), referente às caixas enviadas em 1753 para as partidas encarregadas do norte, foi possível tomar contato com os instrumentos e a literatura que as autoridades lusitanas colocaram à disposição dos seus comissários ${ }^{16}$. Infelizmente ainda não foram encontradas informações dirigidas diretamente à Terceira Partida, enviada ao sul. Mas, levando-se em conta que as duas comissões - norte e sul - foram montadas de forma semelhante, podemos ter como certo que Ciera e seus companheiros também dispuseram de instrumental de ponta, enquanto iam avançando em meio às inumeráveis baías pantaneiras. Barômetro, termômetro, teodolito de Inglaterra, telescópios de diferentes comprimentos - inclusive com micrômetro -, microscópio grande, grafomêtro "em sua caixa com seu pé que the pertence" estavam entre os aparelhos mencionados na Lista. Mas não só isso: relógios de Graham, de pêndulo, com segundos; réguas de ferro, latão, madeira, todas graduadas de diferentes formas: uma, com toesa de Paris; quadrantes grandes e pequenos, tanto o inglês como o francês; estojos de matemática, bússolas - pequenas e grandes - e óculos completavam o arsenal. Foram instrumentos assim que possibilitaram que a cada dia se levasse ao Diário diferentes medições de altura, temperatura, latitudes e longitudes, dando cientificidade às tarefas realizadas ${ }^{17}$.

Na mesma Lista encontramos, ainda, referência aos vários cadernos,
14. Esta Partida portuguesa estava composta por: José Custódio de Sá e Faria, sargento mor de infantaria (com prática de engenheiro), Primeiro Comissário; o doutor Miguel Ciera, cosmógrafo; Gregório de Moraes e Castro Pimentel, Segundo Comissário, capitão de infantaria e ajudante de ordem do Primeiro Comissário; João Bento Pinton, ajudante de infantaria com prática de engenheiro e cosmógrafo; Manuel da Silva, tenente de infantaria e Terceiro Comissário; Antonio Alves Machado, capelão, e José Poliani, cirurgião. Levava também mais de 60 soldados e quase 50 marinheiros, estes para o serviço das canoas, uma vez que esta partida, levou poucos índios como remeiros. Já a tropa espanhola contava com Manuel Antonio de Flores, capitão de fragata da Real Armada, Primeiro Comissário; Athanasio Varanda, tenente de fragata da Real Armada, Segundo Comissário e cosmógrafo; Alonso Pacheco, alferes de navio da Real Armada, cosmógrafo; Manuel de la Quintana, tenente de infantaria; José Quiroga, da Companhia de Jesus, capelão e Pedro García, cirurgião do exército. Levavam ademais 40 soldados para a guarnição da tropa Ver o Diário da terceira Partida de demarcação da América Meridional, Ano de $\mathbf{1 7 5 3}$, em Collecção de notícias (1841, p. 364 -366).

15. Tratado de Madri, 1750.

16. Lista das caixas a serem entregues... (1753). AHU, Brasil, cx.13, doc. 1189.

17. Todas as referências ao Diário contidas neste artigo remetem ao Diário da terceira Partida de demarcação da América Meridional, Ano de 1753, em Collecção de notícias (1841). 
18. AHU - Reino, maço 22, n. 2701.

19. Cf. M. L. Giraldo (1993, p. 130-131).

20. Idem, p. 132-133. de diferentes tipos de papel - de "menor marca", "fino transparente para lucidar desenhos", papel real, próprio "para tirar desenhos em limpo" -, além de tintas em diversas tonalidades "próprias para iluminar", penas, tinteiros, paus de lápis, "boceta com tintas da China com pinceis, papel com gomarabia", materiais que possibilitavam tanto as anotações escritas, como os esboços cartográficos.

Sabemos, entretanto que muitos dos aparelhos não chegaram a ser utilizados. Deve-se ao nosso Miguel Ciera um precioso comentário sobre a questão. Quando Portugal preparava as novas comissões demarcadoras, formadas por força do Tratado de Santo Ildefonso (1777), Ciera alertou: que "não suceda o que aconteceu na minha demarcação: pois então se fizeram gastos muito grandes em comprar instrumentos que não se podiam nem transportar nem armar, e que não eram para o caso, e por isso ficaram totalmente inúteis" 18 .

Certamente, numa viagem como a da Terceira Partida Sul, cuja rota foi exclusivamente fluvial, realizada em pequenos barcos, tornava-se difícil utilizar alguns dos aparelhos acima referidos. Mas, de qualquer maneira, instrumentos houve, pois medições e exações foram feitas e transpostas para as páginas do Diário.

Além disso, foram realizados estudos topográficos e desenhados mapas - além do Mappa geographicum quo flumen Argentum, Paranà et Paraguay aqui estudado -, tal como, hoje, podem constatar-se em acervos americanos e europeus que guardam esse legado; e, para realizá-los, os demarcadores tinham de levar consigo o material necessário.

Comparando-se a Lista portuguesa com a relação "Instrumentos remitidos para las expediciones de Límites" publicada por Lucena Giraldo 19 , pôde-se constatar que lusos e castelhanos rivalizavam quanto à infraestrutura técnica, e que ambas as comissões estavam aparelhadas para o bom êxito das tarefas.

Mas, além desses aparelhos e materiais, as equipes demarcadoras contaram também com o valioso auxílio da câmara escura, instrumento fundamental para apreensão de vistas topográficas. Para as comissões do Maranhão, foram enviadas duas destas câmaras, indicadas "para desenhar Países", e certamente este instrumento esteve na bagagem da Terceira Partida Sul.

Quanto à literatura, tendo em conta a relação dos livros enviados às partidas do Maranhão, podemos perceber que as tropas demarcadoras portuguesas contaram com uma biblioteca- pequena, mas valiosa-, com autores especializados em matemática e astronomia. Ao confrontarmos esta Lista com a relação de livros publicada por Lucena Giraldo ${ }^{20}$, foi possível perceber que portugueses e espanhóis levaram consigo estudos franceses, ingleses e espanhóis. Entretanto, a biblioteca espanhola era um pouco mais laica. Em comum tinham, por exemplo, livros de Bouguer, Clairaut, Cassini, Ulloa e Jorge Juan e La Condamine. Porém Buffon esteve disponível apenas para os comissários de Espanha. Estas informações permitem adentrar no mundo científico que permeou os trabalhos demarcatórios e, também, reconhecer nos expedicionários homens possuidores de uma boa e ilustrada formação acadêmica. 
Assim municiadas, as comissões puderam levar a cabo sua missão. Usando o saber ilustrado, foram simbolicamente se apropriando do lugar, demarcando ali as fronteiras entre colônias ibéricas. $\bigcirc$ uso dos modernos instrumentos e a consulta às obras essenciais de matemática e astronomia possibilitaram reduzir a imensa região a proporções que permitissem uma leitura à distância, mediante o poderoso instrumento que era, e continua sendo, o mapa. E aqui vale lembrar as observações de Fernando Bouza:

A causa última do poder dos mapas radica em que, graças ao mecanismo redutor da escala que introduzem, permitem a representação gráfica de realidades espaciais que o homem não poderia perceber sem sua ajuda. É essa capacidade a que faz possível que sejam utilizados como instrumentos para conhecer o espaço real e, em certo modo, como meio para substituir ou redimensionar a este ${ }^{21}$.

Deste modo, fazendo uso da cartografia, os expedicionários-demarcadores respondiam de forma positiva às exigências dos impérios português e espanhol. Percorreram o interior sul-americano e, sobre o papel, traçaram os lugares recônditos, dando a conhecer os cursos dos rios, as montanhas e as populações que ali habitavam, marcando de forma precisa suas localizações. Isto permitiria aos governantes o efetivo conhecimento dos espaços, possibilitando-lhes racionalizar e atuar sobre eles.

Mas, voltando à viagem...

Esta teve início quando portugueses e espanhóis se encontraram na ilha de Martín García, desembocadura do rio da Prata, em maio de 1753. Ali, José Custódio de Sá e Faria e Manuel Antonio de Flores - vale dizer, os comissários destas partidas - receberam dos comissários principais - Gomes Freire de Andrade e Gaspar Tello y Espinosa, marquês de Valdelirios - as Instrucções que orientariam todos os passos da viagem fluvial ${ }^{22}$. Receberam, também, o Mapa das Cortes, cópia do mapa da região que deviam demarcar, na versão de 1751.

Já em 2 de junho de 1753, a expedição encontra-se em marcha: todo o roteiro constitui-se numa grande jornada fluvial. Nossos expedicionários subiram o rio da Prata, daí ao Paraná, alcançaram as águas do Paraguai, chegando a Assunção, de onde, em 21 de setembro, partiram para a foz do Jauru. A viagem demarcatória, entretanto, só tem início depois que ultrapassaram o trópico de Capricórnio. Dali até o Jauru foi quase dois meses de transcurso fluvial. Durante este tempo, as duas equipes enfrentaram o desafio de reconhecer e cartografar um mundo que thes resultava totalmente estranho. Seu transporte eram as canoas, embarcações de tecnologia indígena; e, mais que meio de locomoção, pelas características do roteiro a seguir, essas pequenas naus se transformaram no âmago da expedição de limites.
21. Cf. a Introdución, de F. Bouza, em Fundación Carlos Amberes (1995, p. 11).

22. "Instrucções que nós os Commissarios Principaes de S. M. F. e de S. M. C. Gomes Freire de Andrade, e Marques de Val de Lírios temos acordado, e firmado para governo dos Commissarios da terceira Partida de demarcação, o Sargento Mor Engenheiro José Custodio de Sá e Faria e D. Manuel Antonio de Flores Tenente Coronel, e Capitão da Fragata Real Armada para que se executem como aqui se prescrevem. Ilha Martins Garcia, 30 maio 1753." Ver Collecção de notícias (1841). 
23. Para Cortesão (2001), trata-se de deformações postas intencionalmente pelos portugueses, com o intuito de passar informações imprecisas que facilitassem as negociações. Carneiro de Mendonça (1985), por sua vez, discorda de Cortesão. Esta questão foi tratada mais recentemente por M. C. Ferreira $(2001 ; 2007)$

24. Diário da terceira Partida de demarcação da América Meridional, Ano de 1753. Ver Collecção de notícias (1841, p. 496; grifos da autora).

25. Ao chegar no Paraguaimini, onde encontraram uma tropa de Cuiabá que os esperava com mantimentos e guias práticos conhecedores dos caminhos, os expedicionários perceberam que, devido às condições climáticas, se quisessem chegar ao Jauru antes que os rios transbordassem, teriam de reduzir a tropa. Isto foi feito e só um pequeno número de demarcadores continuou viagem; Ciera esteve entre aqueles que fixaram o marco divisório.
Quanto às condições de viagem, vale observar que a jornada coincidia com a temporada de chuvas, quando os rios aumentam o volume e suas águas tornam-se velozes correntezas. Navegavam pelo Pantanal, uma região cuja maior singularidade é a de ser um lugar essencialmente aquático. Considerando que viajavam rio Paraguai acima, foi necessário um grande esforço dos remeiros. Chuvas, trovões e relâmpagos eram companheiros constantes, obrigando-os a atrasar as jornadas. E, com as chuvas, chegaram as enfermidades e os infernais mosquitos. Há de se considerar, ademais, que a Partida teve de lidar com a defensiva presença de Guaikuru e Payaguá, que não viam com bons olhos seus dois inimigos viscerais (lusos e espanhóis), com uma numerosa frota de canoas, adentrarem seus ancestrais territórios. Além disso, a estrutura e o tamanho da expedição, somadas às incertezas do caminho, formavam parte da equação a resolver em viagem. O caminho, aliás, foi um dos grandes problemas enfrentados. Não havia práticos para guiá-los.

É certo que levavam o Mapa das Cortes. Para os astrônomos, porém, pouco thes serviu. A todo o momento iam constatando as numerosas falhas contidas nessa carta $^{23}$. A cada averiguação, tornavam-se evidentes os erros de longitude e latitude; nada estava onde deveria estar. Por exemplo, ao chegarem na boca do rio Jauru, os demarcadores anotaram em seu Diário:

E ainda que achamos pelas nossas observações de latitude, que a boca do Jauru está em maior que aquela em que se vê colocada em o mapa de demarcação que nos deram os dois senhores Comissários Principais, não pode servir de embaraço, porque este mesmo erro temos achado em todas as paragens conhecidas, como bocas de rios, e povos, e mais sendo evidente, que por estes sítios não anda quem tenha a inteligência suficiente para este gênero de lavores. ${ }^{24}$

Assim, não só iam identificando os acidentes geográficos, mas, também, corrigindo a cartografia viciada. Isto exigia que os demarcadores, diariamente e em diferentes momentos, tivessem de consultar os aparelhos de medição, trabalho fundamental para os contínuos levantamentos topográficos e cartográficos; e, vale lembrar, tais afazeres só podiam ser executados à luz do dia. Na tropa portuguesa, esse trabalho cabia a Miguel Antonio Ciera e a João Bento Pinton, que atuou como seu ajudante. Finalmente, em 9 de janeiro de 1754, a expedição - ou melhor, parte dela ${ }^{25}$ - avistou o rio Jauru; e poucos dias depois, o marco foi fixado, realizando com êxito a tarefa que thes cabia.

Oatlas

Certamente, como cartógrafo-demarcador, o ofício primeiro de Ciera era o de realizar levantamentos topográficos e traçar mapas, o que efetivamente 
fez. No entanto, paralelo a essas tarefas, tomou apontamentos visuais registrando outros motivos, principalmente lugares e animais.

Isto, entretanto, não se configura como uma singularidade. engenheiro paduano, como os demais profissionais que Portugal contratou no exterior, pós-tratado de Madri, para viajar a América Meridional, deveria ter conhecimentos de geografia, astronomia e de história natural. Mas não só isso. Exigia-se ainda que os estrangeiros fossem "suficientes desenhadores, para tirarem vistas dos lugares mais notáveis, e debuxarem as plantas, animais, e outras coisas desconhecidas, e dignas de notícias" 26 . Respondendo a estas qualidades é que Miguel Ciera foi contratado como astrônomo, matemático e geógrafo - como se Ihe faz referência na documentação -, e transformou-se em membro da Terceira Partida de Limites portuguesa. E de fato, empenhou-se em realizar o que se the exigia. Hoje sabemos que assim o fez.

Como já observado, enquanto esteve no interior sul-americano, nosso personagem levantou mapas, registrou tipos humanos, animais e também a fisionomia de lugares, em vistas topográficas. Testemunho destas suas habilidades são as diversas cartas que desenhou representando a geografia dos rios, com perspectiva dos lugares mais notáveis, como, por exemplo, a que menciona no "Requerimento" ao rei em 1758, já citado. Porém, no conjunto da sua obra, o trabalho, mais espetacular é, sem dúvida, o atlas denominado Mapa geográfico dos rios da Prata, Paraná e Paraguai [...] (Figura 1), que Ciera preparou para D. José I.

Concebido por seu autor como um livro de 36 páginas, este atlas manuscrito ${ }^{27}$, constitui uma obra de singular riqueza, por guardar o primeiro conjunto de vistas da paisagem interior da América Meridional. E, já na sua portada, deixa explicito que se trata de uma obra construída para ser um presente ao rei de Portugal (Figura 2). Aí, alegoricamente, Ciera apresenta uma graciosa figura feminina que, sentada num pedestal, sustenta na mão direita um medalhão oval com o busto de D. José I, em cuja moldura se lê IOSEPHUS I [...] GRAT. PORT. ET ALGAR. REX MDCCLVIII; encerra o conjunto um brasão com as armas de Portugal. A associação do medalhão com um espelho faz pensar que esta bem poderia ser a Prudência, virtude com a qual Ciera associaria a figura do monarca. Mas, especulação à parte, interessa-nos o interior do atlas.

Passada a portada, temos três páginas com os 47 dísticos latinos. Nelas, Ciera relata suas andanças de demarcador, matizando os perigos pelos quais passou durante a longa viagem à América, deixando em evidência que tudo foi feito para glória de Portugal. E, já na folha seis, começa a apresentar graficamente os lugares em mapas e figuras. Ao todo são 31 folhas com desenhos aquarelados, realizados sobre papel de $37 \times 28 \mathrm{~cm}$, nos quais é possível reconhecer que Miguel Ciera era hábil tanto no risco cartográfico, como no das "coisas notáveis": sua mão havia sido adestrada no desenho militar e nas belas artes.

Entretanto, há de se observar que, mesmo sendo um conjunto de representações elaborado em viagem, este trabalho de Miguel Ciera não pode ser entendido como obra de um artista-viajante; figura, aliás, muito mais própria do século XIX ${ }^{28}$. Ciera era, a rigor, um astrônomo demarcador que, seguindo
26. Em Instruçam pela qual se hade regular o M. R. PE Fr. Joam Álvares de Gusmão para buscar, e ajustar alguns geógrafos para o serviço de S. Mage. Ver em J. Cortesão (1952, p. 21-25)

27. Por motivo de conservação, o livro foi desencadernado e suas páginas são guardadas, como folhas avulsas, no Seção de Cartografia da Fundação Biblioteca Nacional do Rio de Janeiro. Há uma descrição dele em J. Cortesão (1972, t. II, p. 285289).

28. Ver P. Diener (1996, p. 63). 


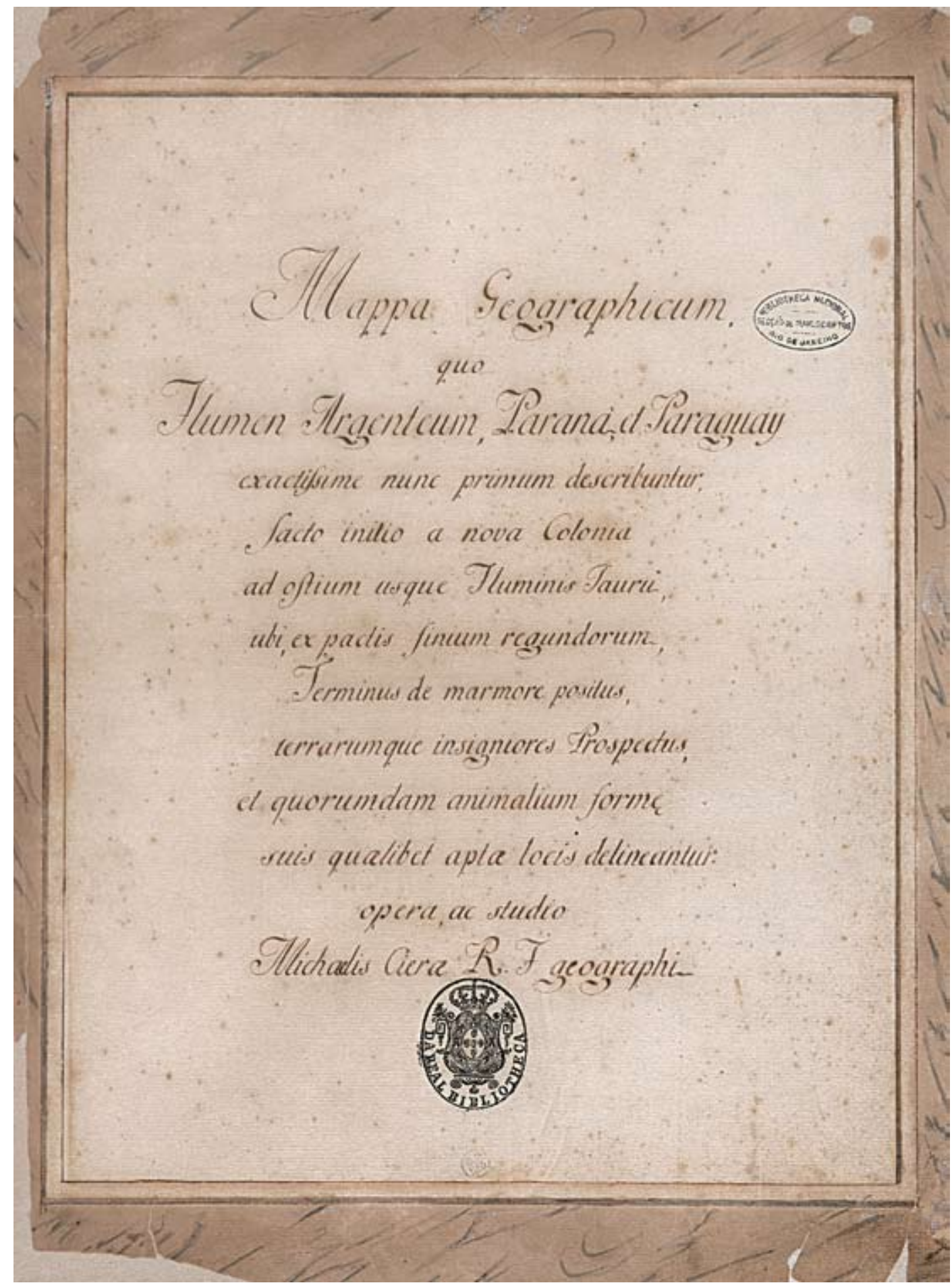

Figura 1 - Página com o título do atlas Mapa geográfico dos rios da Prata, Paraná e Paraguai [...]. Autor: Miguel Ciera, 1758. Dimensão: $37 \times 28 \mathrm{~cm}$. Acervo da Fundação Biblioteca Nacional, Rio de Janeiro. 


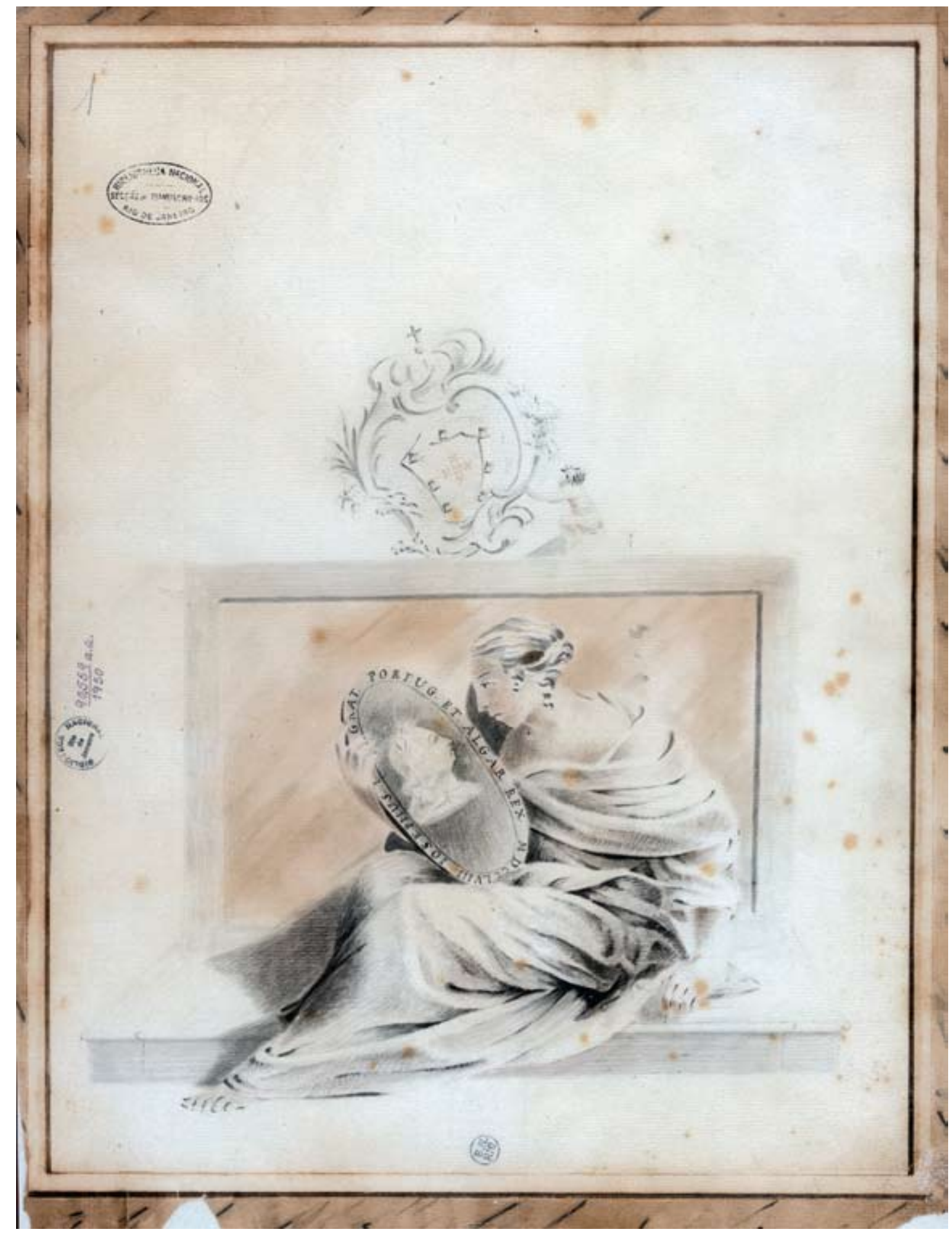

Figura 2 - Portada do atlas. Miguel Ciera, 1758. Lápis, tinta e aquarela sobre papel. Dimensão: $37 \times 28 \mathrm{~cm}$. Acervo da Fundação Biblioteca Nacional, Rio de Janeiro. 
29. Tomou-se como referência o conceito definido por Norman J. W. Thrower, (2002, p. 101)

30. Este quadro pretende dar uma idéia sobre a estrutura da obra, tal como montada por Miguel Ciera. Tomou-se como referência a disposição das folhas no livro, numerando-as de 1 a 35. A partir daí seu conteúdo foi dividido em dois grandes conjuntos: "motivos vários" e "cartas geográficas" - neste respeitou-se a numeração em romano, dada pelo autor. ordens do reino, também se esmerou em realizar uma documentação visual sobre fauna e lugares considerados estratégicos, como se the havia solicitado. E é nesse contexto que sua obra deve ser lida e entendida.

Assim, ao desenhar, a preocupação primeira deste demarcador era a de fornecer elementos visuais que servissem de suporte complementar aos levantamentos geográficos que então se realizavam: e é isto o que aparece nas folhas do álbum que elaborou. Tanto assim que o motivo principal da obra é o Mapa geográfico dos rios da Prata, Paraná e Paraguai, que the dá título.

Trata-se, pois, de um mapa temático ${ }^{29}$. Mas Miguel Ciera preferiu desenhá-lo trecho a trecho, em quinze diferentes folhas. Estas, entretanto, apesar de numeradas de I a XV, não foram postas em ordenamento contínuo. Ao montar a sua obra, escolheu intercalar motivos, alternando cartas geográficas com folhas onde representou plantas topográficas, vistas de lugares e animais. Assim, para se conhecer o Mappa de forma integral, é necessário ordenar as cartas de acordo com a sequência numérica que o autor the deu. Feito isso, surge, em minúcias, toda a região banhada pelos grandes rios platinos, desde a foz do Prata - no Atlântico - até o Jauru, quando as águas deste rio adentram no Paraguai.

Tendo-se em conta os motivos apresentados, o atlas nos oferece dois conjuntos de informações: uma cartográfica e outra iconográfica, como se sintetiza no quadro na página seguinte.

Há de se registrar, entretanto, que o conjunto iconográfico apresentado não se restringe apenas às folhas que no quadro estã denominados como de "motivos vários". Além delas, Ciera incluiv em todas as cartas - exceto na carta XIV - interferências pictóricas que vão desde sutis detalhes barrocos até complexas e pesadas formas arquitetônicas, marcadamente neoclássicas. Em meio a essas há lugar para personagens mitológicos, como um cupido, e para grupos de figuras humanas. Contudo, tais elementos ainda precisam ser melhor analisados para se entender seus significados, pois, certamente, não são meras ilustrações. Por enquanto podemos dizer, apenas, que o conjunto decorativo mostra que, além de ser um excelente cartógrafo, Miguel Ciera tinha uma boa formação em desenho.

Esse juízo, porém, não pode ser estendido às folhas que trazem representações de animais. Neste caso o engenheiro-demarcador indicou que os traços da História Natural não eram o seu forte. É certo que suas aves são até graciosas, mas o tamanduá e o lagarto denotam uma total falta de familiaridade com este tipo de desenho. Talvez por isso tenha criado ingênuos fundos paisagísticos, que pouco dialogam com as figuras apresentadas. De fato, os animais formam o conjunto mais pobre dentre as imagens representadas neste belo atlas.

Mas, voltando às informações sintetizadas no quadro, percebe-se que o autor, ao eleger dois tipos de motivos para compor a sua obra, contrapõe o conjunto iconográfico ao cartográfico; isto possibilitava que o seu real leitor recebesse múltiplas informações sobre os lugares nos quais se demarcava a fronteira em seus domínios sul-americanos. Ao folhear o atlas, D. José conheceria tanto a geografia como os aspectos mais interessantes da região. 
Quadro sintético das imagens contidas no Atlas de Miguel Ciera ${ }^{30}$

\begin{tabular}{|c|c|c|c|}
\hline & Motivos vários & & Cartas Geográficas \\
\hline p. 6 & $\begin{array}{l}\text { Colônia de Sacramento - folha dividida em } 2 \\
\text { quadros: planta e vista interior de Colônia }\end{array}$ & p. 7 & I. Foz do rio da Prata e rio Uruguai, paralelo $34^{\circ}$. \\
\hline p. 8 & Ave / Pardal & p. 9 & II. Rio Paranaguaçu \\
\hline p. 10 & Ave /Tyma-puçu & p. 11 & III. Rio Paraná até o rio Calcaranha \\
\hline p. 12 & Ave/ Colhereira & p. 13 & IV.Rio Paraná, paralelo $31^{\circ}$. \\
\hline p. 14 & Quadrúpede / Tamanduá & p. 15 & V. Rio Paraná, paralelo $30^{\circ}$. \\
\hline p. 16 & Ave / Jacutinga & p. 17 & $\begin{array}{l}\text { VI. Rio Paraná, até o arroio São Lourenço, paralelo } \\
19^{\circ} \text {. }\end{array}$ \\
\hline p. 18 & Ave / Myłu & p. 19 & VII. Rios Paraná e Paraguai, paralelo $28^{\circ}$. e $27^{\circ}$. \\
\hline p. 20 & Réptil / Lagarto & p. 21 & $\begin{array}{l}\text { VIII. Rio Paraguai, desde o Vermelho ao Pilcomayo, } \\
\text { paralelo } 26^{\circ}\end{array}$ \\
\hline p. 22 & $\begin{array}{l}\text { Paraguai - folha dividida em } 5 \text { quadros: mulher e } \\
\text { homem paraguaios; vistas das Pedras de Santa } \\
\text { Catarina e vista da cidade de Assunção do Paraguai }\end{array}$ & p. 23 & Carta IX - rio Paraguai, paralelo $25^{\circ}$. \\
\hline p. 24 & Ave / Toucãn & p. 25 & $\begin{array}{l}\text { X. Rio Paraguai, desde o rio Xejui a ilha do defunto } \\
\text { Manuel Dias; paralelos } 23^{\circ} \text { e } 24^{\circ} \text {. }\end{array}$ \\
\hline p. 26 & $\begin{array}{l}\text { Paisagens - folha dividida em } 2 \text { quadros: vistas da } \\
\text { serra do Pão de Açúcar }\end{array}$ & p. 27 & $\begin{array}{l}\text { XI. Rio Paraguai, desde Itapocú-mirim até o rio } \\
\text { Costa del Querquincho }\end{array}$ \\
\hline p. 28 & $\begin{array}{l}\text { Paisagem - folha dividida em } 3 \text { quadros: vista do } \\
\text { morro } 3 \text { Irmãos e vistas da serra do Pão de Açúcar. }\end{array}$ & p. 29 & $\begin{array}{l}\text { XII. Rio Paraguai, desde o Estreito, Pão de } \\
\text { Açúcar; paralelo } 21^{\circ} \text {. }\end{array}$ \\
\hline p. 30 & $\begin{array}{l}\text { Paisagem - folha dividida em } 6 \text { quadros com vistas } \\
\text { da cordilheira de São Fernando. }\end{array}$ & p. 31 & $\begin{array}{l}\text { XIII. Rio Paraguai, até o morro dos Cavaleiros } \\
\text { [Guaikuru]; paralelos } 19^{\circ} \text { e } 20^{\circ}\end{array}$ \\
\hline p. 32 & $\begin{array}{l}\text { Paisagem - folha dividida em } 5 \text { quadros: vista da } \\
\text { lagoa Gaíba; vista da cordilheira de São Fernando } \\
\text { e vistas dos morros Chané. }\end{array}$ & p. 33 & $\begin{array}{l}\text { XIV. Rio Paraguai, desde o Paraguai-Mini } \\
\text { até a ilha Comprida e lagoa Uberaba }\end{array}$ \\
\hline p. 34 & $\begin{array}{l}\text { Paisagem - folha divida em } 2 \text { quadros: vista do } \\
\text { lugar donde se tem posto o marco do Jauru e vista } \\
\text { do rio Paraguai, para cima do rio Jauru }\end{array}$ & p. 35 & $\begin{array}{l}\text { XV. Rio Paraguai, desde os Pantanais que se } \\
\text { inundam nas cheias, até a embocadura do rio } \\
\text { Jauru, onde se encontra o marco de mármore. }\end{array}$ \\
\hline
\end{tabular}

Entretanto, Ciera também permite que o atlas seja visto de outra maneira; acreditamos, inclusive, que essa segunda leitura espelha a forma na qual o autor refletidamente arquitetou a obra, voltando-a para as questões estratégicas que mediaram o trabalho. Neste caso, o critério predominante é geográfico e diz respeito ao roteiro de viagem realizado pela Terceira Partida. Seguindo-o, com a ajuda das impressões contidas no Diário, salta aos olhos que o livro está 
dividido em duas grandes partes. A primeira corresponde ao percurso fluvial realizado da Colônia de Sacramento até a cidade de Assunção do Paraguai (folhas 6 a 24); e a segunda cobre o trajeto realizado desde o trópico de Capricórnio até a boca do rio Jauru (follhas 25 a 35).

Considerando que, tal como informa o Diário, a viagem demarcatória só teve início em 11 de novembro de 1753, quando a expedição ultrapassou aquele trópico, claro está que Ciera reservou a primeira parte do seu livro para fornecer informações unicamente sobre o território espanhol sul-americano, da foz do Prata a Assunção. Com isto, oferecia a D. José um conhecimento pormenorizado dos lugares que, por questões de segurança, sempre esteve vedado aos portugueses. Intercalando cartas geográficas com os outros temas, nosso astrônomo dá a conhecer as precisas localizações e ainda as "coisas notáveis" que ali existiam.

Cabe observar, entretanto, que é nesta parte do livro que se reúnem as representações da fauna; com exceção de duas folhas - a primeira e a penúltima - nas quais Miguel Ciera apresenta a Colônia de Sacramento e diferentes aspectos da Cidade da Assunção do Paraguai, as demais estão dedicadas a aves e outros animais.

Já a segunda parte do seu livro foi reservada para tratar do território fronteiriço, por onde efetivamente se desenvolveu a viagem de demarcação. Nela o autor apresentou seis cartas detalhadíssimas do curso do rio Paraguai - desde o seu deságue no Paraná até receber a águas do Jauru - e cinco vistas topográficas de monumentos naturais. Sem dúvida, esta é a parte mais rica do atlas, tanto por seu conteúdo geográfico como, principalmente, pelo iconográfico. É nela que se concentra a representação da paisagem.

Tendo como norte o critério estratégico, vemos que não é por acaso que o primeiro lugar representado neste atlas seja a Colônia de Sacramento. Objeto de disputas entre os estados ibéricos, esta praça fortificada, fundada pelos portugueses em 1680, era um dos pontos nodais da demarcação. Por força do Tratado de Madri, Sacramento passaria à posse dos espanhóis e, em troca, estes dariam a Portugal o território dos Sete Povos das Missões. Portanto, naquele momento, tratava-se de um lugar cuja posse ainda estava em litígio.

Para representá-la, Ciera dividiu a folha em duas metades desiguais (Figura 3): na parte superior, desenhou a planta da cidadela; e, na inferior, uma vista interna, a que chamou Vista por dentro da Praça da Colônia. Nela, acrescentou elementos costumbristas em primeiro plano. Vemos, então, um grande largo, margeado de casas bem construídas (algumas assobradadas), e edifícios religiosos, indícios de que se tratava de um núcleo urbano organizado e bem povoado.

Tratando-se, porém, de território espanhol, sua atenção maior, em termos de documentação visual, recaiu sobre a região de Assunção. Afinal era uma oportunidade ímpar para que os portugueses pudessem conhecer aquela cidade. Ciera, então, esmerou-se em sintetizar informações, escolhendo temas pontuais: população, paisagem e a própria cidade (Figura 4). Seguindo esse 


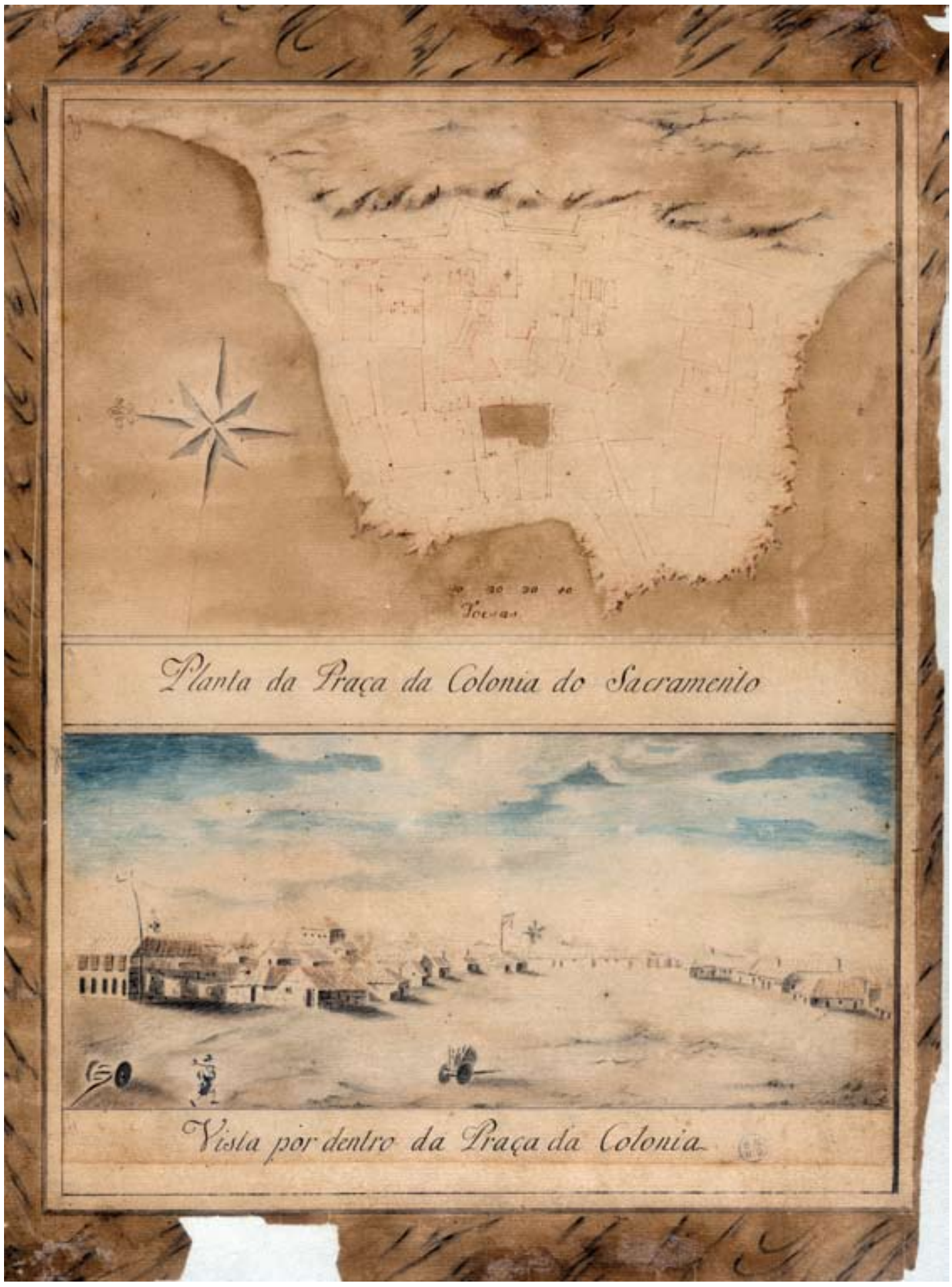

Figura 3 - I. Planta da Praça da Colônia de Sacramento. II. Vista por dentro da Praça da Colônia. In: Atlas Mapa geográfico dos rios da Prata, Paraná e Paraguai [...]. Autor: Miguel Ciera, 1758. Lápis, tinta e aquarela sobre papel. Dimensão: 37 × $28 \mathrm{~cm}$. Acervo da Fundação Biblioteca Nacional, Rio de Janeiro. 


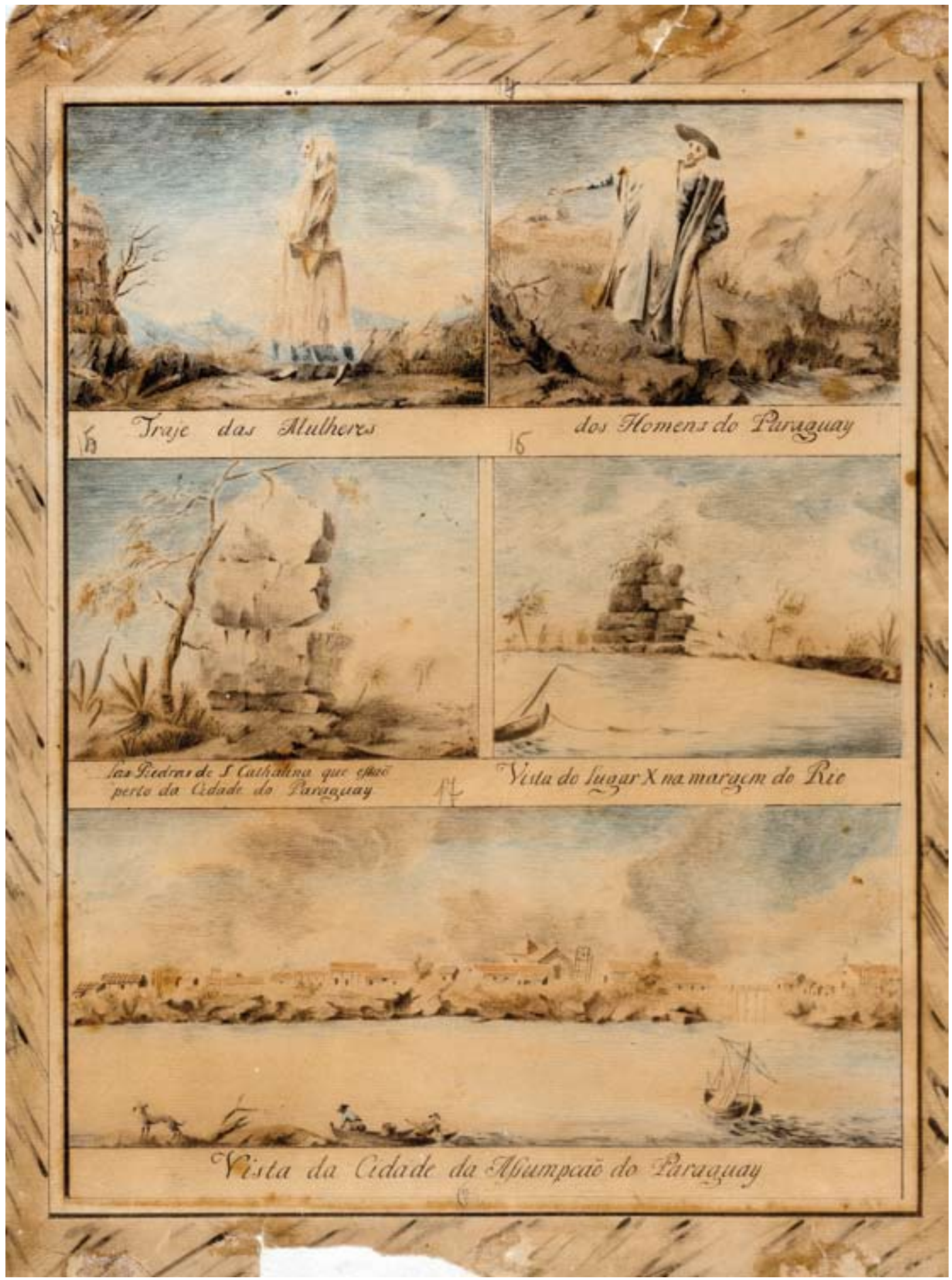

Figura 4 - I. Traje das mulheres e dos homens do Paraguai. II. As Pedras de Santa Catarina. III. Vista da Cidade da Assunção do Paraguai. In: Atlas Mapa geográfico dos rios da Prata, Paraná e Paraguai [...]. Autor: Miguel Ciera, 1758. Lápis, tinta e aquarela/ papel. Dimensão: $37 \times 28 \mathrm{~cm}$. Acervo da Fundação Biblioteca Nacional, Rio de Janeiro. 
programa, dividiu uma das folhas em três partes e aí lançou seus traços. Na parte inferior, deu forma a uma vista panorâmica da Cidade da Assunção do Paraguai, onde é acentuada a localização ribeirinha, deixando ver toda a silhueta urbana que se estende sobre um alto barranco, às margens do Paraguai. Na parte central, subdividiu a folha em dois pequenos quadros e neles apresenta as Pedras de Santa Catarina, mostrando-as isoladas e em vista panorâmica; a ênfase é dada também à sua localização ribeirinha. E, coroando a página, dá a conhecer a mulher e o homem que ali vivem, representando-os ataviados em seus trajes típicos. Vemos, pois, que o conjunto de informações depositado nesta folha pelo desenhista-demarcador a transforma, graficamente, num documento visual de primeira linha, elaborado com atenção e requinte.

Mas é na segunda parte do atlas que Ciera demonstra toda sua habilidade de cartógrafo e documentador visual. Inicia apresentando a Carta X, onde registra geograficamente a região em que os comissários decidiram "de comum acordo principiar a demarcação", ou seja, do Trópico de Capricórnio para cima, como assinalaram no Diário ${ }^{31}$. Mas, como se não bastasse, remarcou esta indicação com elementos gráficos, criando, em primeiro plano, na parte inferior do mapa, uma cena inequivocamente alusiva ao feito. Ao centro, representou um monumento de pedra em forma de pirâmide quadrangular, tal um marco divisório (Figura 5). À esquerda deste, projetou uma grande e alta muralha, dando-the o aspecto de fortaleza e, para protegê-la, deu corpo a um jovem sentinela que, com veste militar e armado de lança, olha altivamente para o leitor. A seus pés está outro homem; este, de feições indígenas, mira diretamente o marco.

Trata-se de um trabalho primoroso em significados. Com esta carta, Miguel Ciera mostra em mapa e figuras, o local onde, efetivamente teve início o reconhecimento e a demarcação da fronteira; indica, ainda, que se tratava de um lugar a ser militarmente defendido, e traz uma alusão, sutil, à submissão e incorporação do índio como súdito e guardião - questão, vale lembrar, então de grande interesse lusitano.

A partir desta, todas as folhas - da XI a XV - trazem cartas geográficas que mostram em detalhes os lugares por onde, de acordo com o Tratado de Madri, passaria a linha de limites. Contrapondo a estas, o demarcador levou ao papel a fisionomia da paisagem que se transformava em fronteira. É assim que o atlas idealizado por Miguel Ciera se torna mais atrativo, propondo um jogo de imagens, com mapas e vistas dialogando intensamente. E vão surgindo delicadas aquarelas apresentando, por exemplo, o morro Três Irmãos e a serra do Pão de Açúcar (Figura 6) e, claro, o rio Jauru, em cujas barrancas o marco de mármore foi "plantado" (Figura 7). Para poder realizá-las, Ciera certamente contou com o auxílio da câmara escura: afinal, esse instrumento era próprio para "desenhar Países".

Estava, pois, criado o primeiro conjunto visual da paisagem pantaneira. Seguindo os conceitos de Svetlana Alpers, podemos designar estas vistas de "paisagens cartográficas" 32 .
31. Diário. Ver Collección de notícias (1841, p. 370).

32. Cf. S. Alpers (1999, p. 249). 


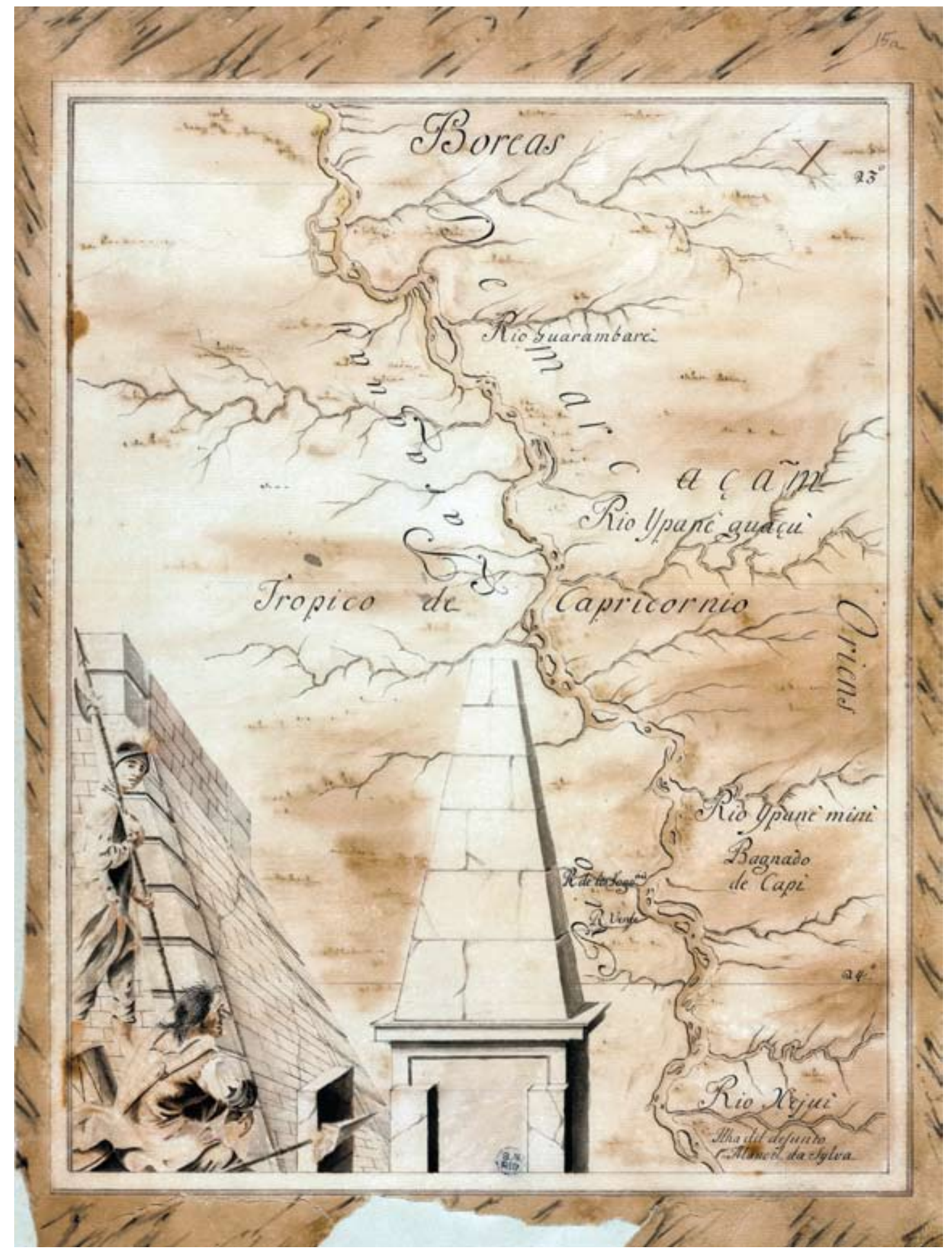

Figura 5 - Carta X. Rio Paraguai. In: Atlas Mapa geográfico dos rios da Prata, Paraná e Paraguai [...]. Autor: Miguel Ciera, 1758. Lápis, tinta e aquarela sobre papel. Dimensão: $37 \times 28 \mathrm{~cm}$. Acervo da Fundação Biblioteca Nacional, Rio de Janeiro. 


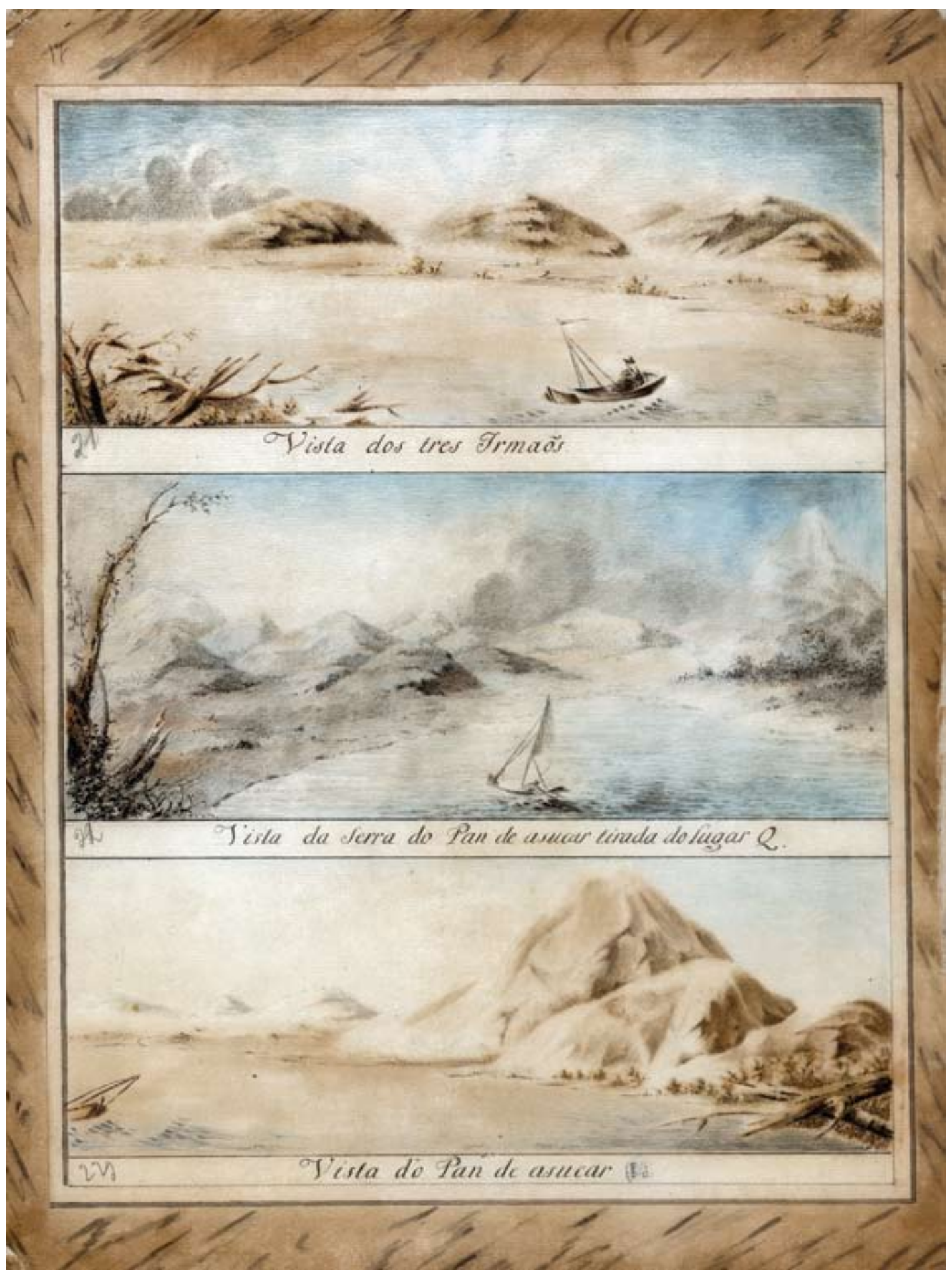

Figura 6 - I. Vista dos Três Irmãos. II. Vista da Serra do Pão de Açúcar. III. Vista do Pão de açúcar. In: Atlas Mapa geográfico dos rios da Prata, Paraná e Paraguai [...]. Autor: Miguel Ciera, 1758. Lápis, tinta e aquarela sobre papel. Dimensão: $37 \times 28 \mathrm{~cm}$. Acervo da Fundação Biblioteca Nacional, Rio de Janeiro. 


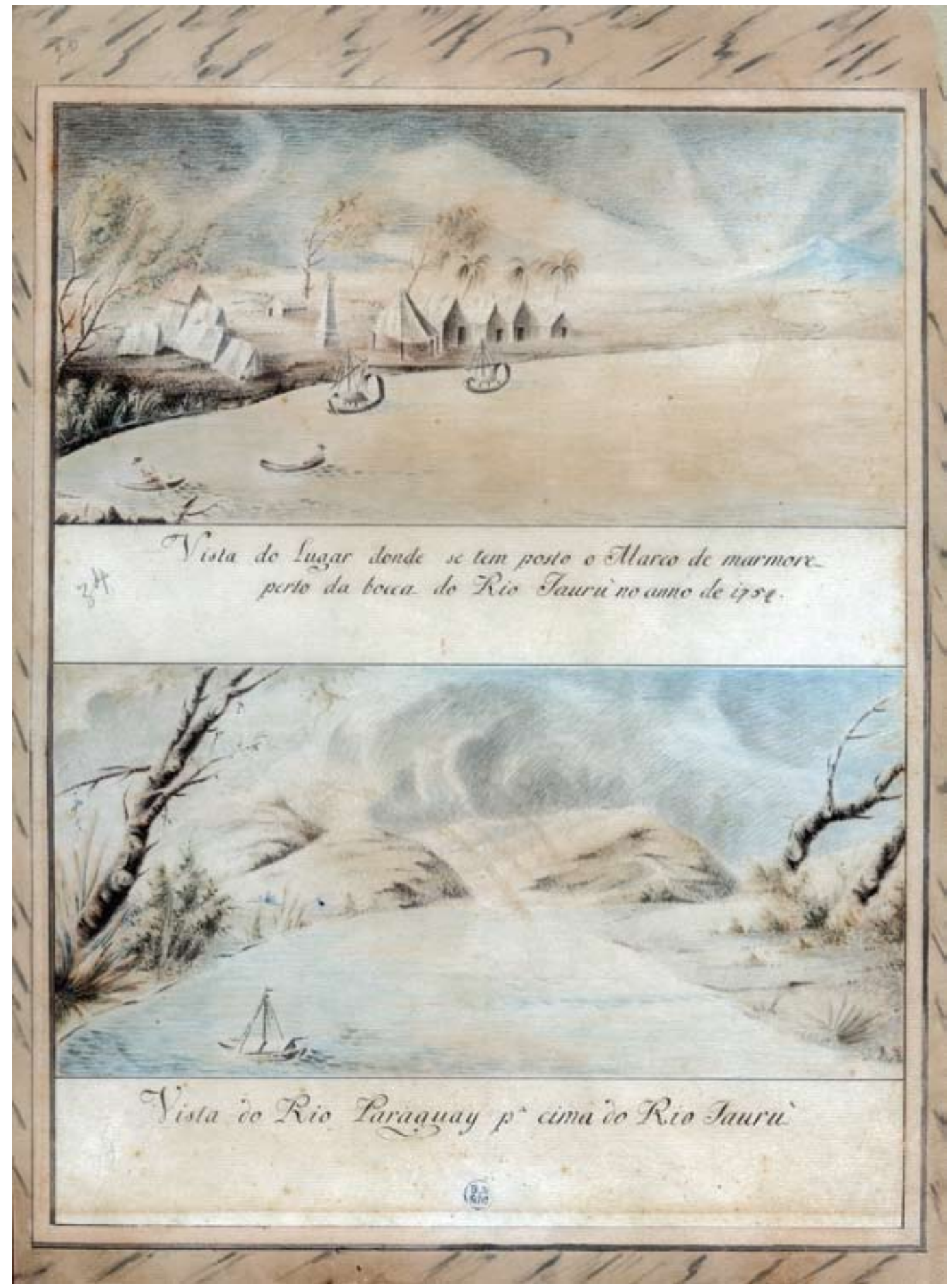

Figura 7 - Vista do Lugar onde se colocou a Marco de Limites. Vista do rio Paraguai acima do rio Jauru. In: Atlas Mapa geográfico dos rios da Prata, Paraná e Paraguai [...]. Autor: Miguel Ciera, 1758. Lápis, tinta e aquarela sobre papel. Dimensão: $37 \times 28 \mathrm{~cm}$. Acervo da Fundação Biblioteca Nacional, Rio de Janeiro. 
Merecem destaque, nessas representações, as paisagens contidas na página 32 do atlas. Nela Miguel Ciera desenhou a fisionomia de um dos lugares mais emblemáticos da fronteira que se demarcava: exatamente a mítica região que, até aquele período, era denominada pelos castelhanos de Laguna de los Xarayes, e, no texto do Tratado de Madri, foi referida como "os pântanos que formam este rio [o Paraguai], chamados a Lagoa dos Xarais". Certamente, a escolha deste lugar como motivo não foi fruto do acaso.

Desde os relatos dos primeiros espanhóis que chegaram à bacia do rio da Prata, a lagoa de Xarayes foi um espaço que deu pé à construção de narrativas fantásticas. Acreditava-se que ali existiam riquezas e seres maravilhosos, o que constituiu uma imagem bastante conhecida. E, a partir de meados do século $X V I I$, quando os holandeses a desenharam em seus mapas, a lagoa passou a ser objeto de curiosidade universal. Admitia-se, também, com base nos mapas jesuítas, que era nela que nascia o rio Paraguai.

Foram os expedicionários das terceiras partidas, ao concluírem a viagem, que perceberam ser a famosa lagoa nada mais que as águas do rio Paraguai, quando este se espraia no período de cheia ${ }^{33}$. No momento da própria demarcação, porém, Xarayes ainda era um dos focos de dúvidas geográficas. Nesse particular, vale à pena transcrever os comentários que nos legou o jesuíta-matemático José Quiroga, capelão da tropa espanhola:

No dia 21 [de janeiro de 1754], às oito da manhã, chegamos à boca estreita de uma lagoa [...] que os portugueses chamam a Lagoa Grande, e contam dela muitas fábulas. Duvidaram os Comandantes se acaso estaria aqui o grande lago de los Xarayes, e para desenganar-se, entramos pela estreita boca com os quatro barcos, e em meio dia a registramos toda [...]. Os portugueses disseram que havia à entrada uma penha que teria gravadas as armas do Rei de Portugal, e que naquela lagoa havia animais ferozes, que não havia entrado homem nela que não tivesse sido tragado. Nós entramos até o último e voltamos a sair, sem haver visto tais armas nem animais [...]; não vimos na dita lagoa nem animal, nem ave, nem coisa alguma, que não água que parecia ter a cor algo verde. Navegamos esta tarde a remo. Esta, ao meu juízo, é a lagoa Maniorée ${ }^{34}$.

Então, não é à toa que Miguel Ciera reteve a fisionomia paisagística deste enigmático lugar; além disso, era uma região que se tornava fronteira.

Para retratá-la, o engenheiro paduano dividiu uma das folhas do seu livro em quatro grandes campos, subdividindo, ainda, um deles em duas metades. Na faixa superior, mostrou a vista interior da lagoa Gaíba, em seguida, deu forma à cordilheira de São Fernando, assinalado que a representação foi "tirada do lugar $A^{\prime \prime}$; e, por último, na parte inferior da folha, registrou os morros Chané em dois diferentes ângulos, um tirado "do lugar C" e outro do "lugar B".

Porém, para entender todo este conjunto paisagístico, é indispensável contrapor as informações visuais nelas contidas, àquelas que o mesmo demarcador desenhou na carta geográfica (a de número XIV), na qual as letras ganham significado (Figuras 8 e 9).

Assim, os registros de Miguel Ciera devem ser estudados e entendidos
33. Sobre o assunto, consultar M de F. Costa (1999; 2007).

34. Cf. José Quiroga (1892, p. 429) 


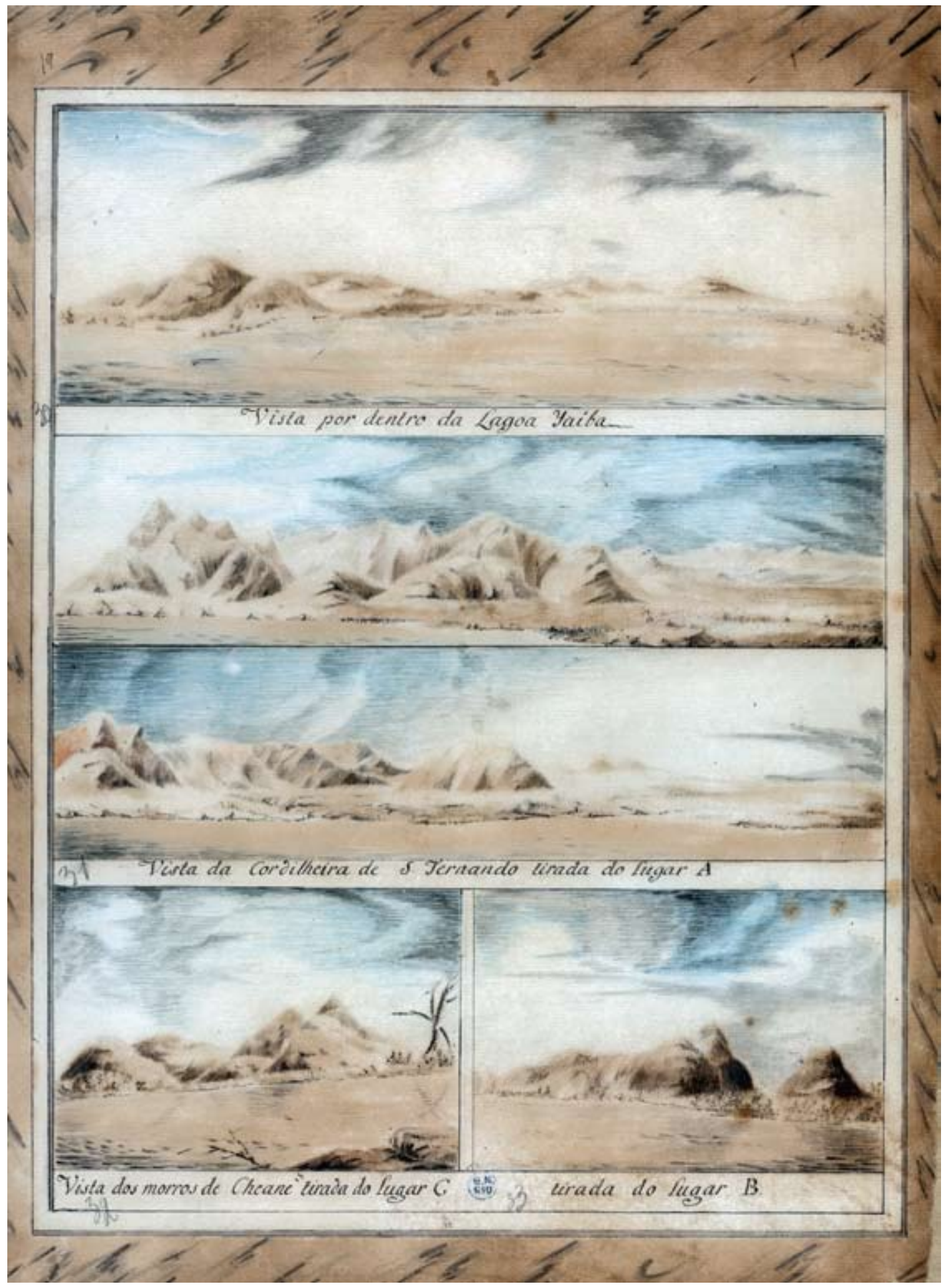

Figuras 8 - I. Vista da lagoa Gaíba. II. Vista da cordilheira de São Fernando. III. Vista dos morros Chané. In: Atlas Mapa geográfico dos rios da Prata, Paraná e Paraguai [...]. Autor: Miguel Ciera, 1758. Lápis, tinta e aquarela sobre papel. Dimensão: $37 \times 28 \mathrm{~cm}$. Acervo da Fundação Biblioteca Nacional, Rio de Janeiro. 


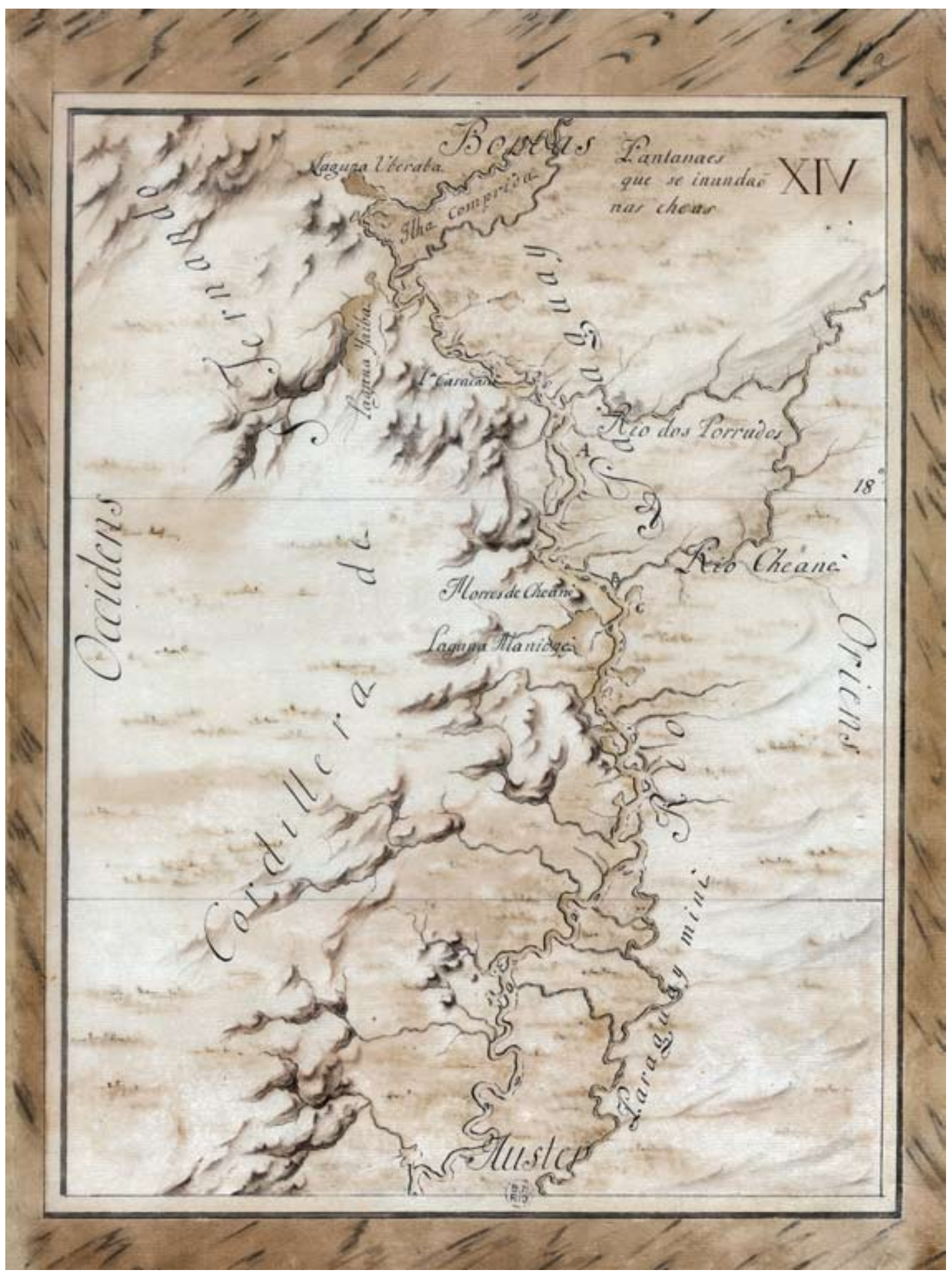

Figuras 9 - Carta XIV. Rio Paraguai. In: Atlas Mapa geográfico dos rios da Prata, Paraná e Paraguai [...]. Autor: Miguel Ciera, 1758. Lápis, tinta e aquarela sobre papel. Dimensão: $37 \times 28 \mathrm{~cm}$. Acervo da Fundação Biblioteca Nacional, Rio de Janeiro. 
no contexto da demarcação. Ao desenhar a paisagem, o astrônomo tinha em mente criar um documento visual complementar aos mapas. Por isso, há um diálogo constante entre as paisagens cartográficas e as cartas geográficas, que só se faz inteligível lendo-as de forma conjunta, a partir do universo no qual foram geradas.

Se olharmos as aquarelas isoladamente, podemos inclusive tomá-las como representações da paisagem, com conotações românticas, evocando um sentimento de solidão, que parece acentuado pela leveza do traço e pelas tonalidades das cores usadas. Mas esta linha de interpretação é extemporânea. Nestas folhas, águas e montanhas parecem querer existir por si mesmas, sob um céu que enuncia ventos e chuvas - tal como descrito no Diário; e, no atlas, estão estreitamente vinculadas a uma carta geográfica específica. Isto é, a paisagem só ganha significado quando contraposta à carta dos rios com a qual dialoga.

Vemos, pois, que, ao presentear o rei D. José com este atlas, Miguel Ciera dava-the a possibilidade de conhecer - em mapas e imagens - 0 interior da América Meridional. Nele destacou, propositadamente, aspectos diferenciados da fisionomia dos lugares que visitou: por um lado, as terras espanholas; por outro, e principalmente, a linha de fronteira. Ao representar esta foi que, particularmente, esforçou-se em fornecer as coordenadas geográficas precisas, mas - e sobretudo - a fisionomia dos monumentos naturais, com os rios e as montanhas que se tornavam balizas de limites. Ao mesmo tempo, oferecia ao monarca lusitano um belo documento ilustrado sobre os lugares que, pelo Tratado de Madri, passavam a pertencer ao Império Português.

Na perspectiva histórica, porém, o cartógrafo paduano legava-nos também a representação inaugural do interior sul-americano, notadamente da paisagem do Pantanal.

Em 1761 o Tratado de Madri foi anulado, desfazendo-se as demarcações. Mas não se perderam os conhecimentos que Ciera e seus companheiros proporcionaram sobre esta região. Certamente, no caso de Portugal, foram bem aproveitados pelos seus discípulos Antonio Pires da Silva Pontes e Francisco José de Lacerda e Almeida, que, na década de 1780, voltaram à região, como membros de outra Terceira Partida de Limites, agora por força do Tratado de Santo Ildefonso.

\section{REFERÊNCIAS}

\section{FONTES ICONOGRÁFICAS}

CIERA, Miguel. Mappa geographicum quo flumen Argentum, Paranà et Paraguay exactissime nunc primum describuntur, facto inito a nova Colonia ad ostium usque fluminis iauru ubi, ex pactis finuim regundorum, Terminus de mármore positus, terrarumque insigniores Prospectus, et quorundam animalium forme suis quaelibet aptae delineantur. Opera, ac Studio Michaelis Ciera R. F. geographi. 1758. Fundação Biblioteca Nacional do Rio de Janeiro. CAM. 02, 001. 
FONTES IMPRESSAS

COLLECÇÃO de notícias para a História e Geografia das Nações Ultramarinas que vivem nos domínios portugueses ou lhes são visinhas, VII. Lisboa: Academia Real das Sciencias, 1841.

TRATADO de Madrid. Lisboa: Imprensa de Joseph da Costa Coimbra, 1750.

QUIROGA, José. Breve notícia del viaje que hizo el Padre José Quiroga por el rio Paraguay con la partida que fue á poner el marco en la boca del Jaurú (1753-1754) (Copia moderna de otra del original de su mano). In: LA FUENSANTA DEL VALLE, Marques (Org.). Collecion de documentos inéditos para la História de España, 104. Madrid: Imprenta de José Perales y Martinez, 1892, pp. 407-448. Disponível em: <http://www.archive.org/details/coleccindedocu104madruoft>. Acesso em 12 nov. 2009.

\section{FONTES MANUSCRITAS}

Arquivo Histórico Ultramarino. Brasil, cx. 13, doc. 1189 (1753).

Brasil - Limites, cx. 1, doc. 93 (25 dez. 1755).

Brasil - Rio de Janeiro, cx. 85, doc 19.643 (5 maio [mar.] 1756).

Brasil - Rio de Janeiro, cx. 188, doc. 13577.

Reino, maço 22, n. 2701.

OBRAS GERAIS

ALPERS, S. A arte de descrever. São Paulo: Edusp, 1999.

BOUZA, F. Introdución. In: FUNDACIÓN CARLOS AMBERES (ed.). De Mercator a Blaeu. España y la Edad de Oro de la cartografía en las diecisiete provincias de los Países Bajos: catálogo. Madrid: Fundación Carlos de Amberes, 1995. p. 11-17.

CARVALHO, R. História da fundação do Colégio Real dos Nobres de Lisboa. Coimbra: Atlântida, 1959.

A astronomia em Portugal no século XVIII. Lisboa: Instituto de Cultura e Língua Portuguesa, Ministério da Educação, 1985.

CORTESÃO, J. (org.). Alexandre de Gusmão e o Tratado de Madrid (1750), V. Rio de Janeiro: Ministério das Relações Exteriores, 1952.

História do Brasil nos velhos mapas, II. Rio de Janeiro: Ministério das Relações Exteriores, 1972.

O Tratado de Madrid. Ed. fac-sim. Brasília: Editora do Senado Federal, 2001.

COSTA, M. de. F. História de um país inexistente. Pantanal entre os séculos XVI e XVIII. São Paulo: Estação Liberdade; Kosmos, 1999. 
COSTA, M. de F. De Xarayes ao Pantanal: a cartografia de um mito geográfico. Revista do IEB, São Paulo, n. 45, p. 21-37, 2007.

DIENER, P. El perfil del artista viajero en el siglo XIX. In: Viajeros europeus del siglo XIX en México. Ciudad de México: Fomento Cultural Banamex, 1996. p. 63-85.

FERREIRA, M. C. O Mapa das Cortes e o Tratado de Madrid, a cartografia a serviço da diplomacia. Varia História, v. 23, n. 37, p. 51-69, 2007.

O Tratado de Madrid e o Brasil Meridional. Lisboa: Comissão Nacional para as Comemorações dos Descobrimentos Portugueses, 2001

GIRALDO, M. L. Laboratorio Tropical. La expedición al Orinoco (1750 -1767). Madri: CSIC; Caracas: Monte Ávila, 1993.

MENDONÇA, M. C. de. Rios Guaparé e Paraguai primeiras fronteiras definitivas do Brasil. Rio de Janeiro: Xerox do Brasil, 1985.

MERÁS, L. M. Cartografía marítima hispana. La imagen de América. Madri: Lunwerg; CSIC, 1993.

THROWER, Norman J.W. Mapas y civilización. Historia de la Cartografia en su contexto cultural y social. Barcelona: Del Serbal, 2002..

Artigo apresentado em 8/2008. Aprovado em 3/2009. 